\title{
On the Translation Memetics for Archeology Text: A Case Study of the Archaeological Excavations at Royal Cemetery of Haihunhou State in Han Dynasty* $^{*}$
}

\author{
Cheng Dai \\ Foreign Languages College, Jiangxi Normal University, Nanchang, China \\ Yuying Li \\ Foreign Languages College, Jiangxi Normal University, Nanchang, China
}

\begin{abstract}
Memetics, based on Darwin's evolutionism, explains the process of cultural evolution from cultural perspective whose core content is the imitation and replication of the form and meaning of memes under the different contexts. Coupled with colorful pictures, The Archaeological Excavations at the Royal Cemetery of Haihunhou State in the Han Dynasty records the most famous archaeological excavations in Nanchang, Jiangxi, China in recent years. This paper studies the dissemination ways in archeology translation in the book and finds out the respective characteristics of genotypic translation and phenotypic translation, so as to examine and explain the translation phenomena from the perspective of translation memetics, aiming to provide a new theoretical direction for the study of archeology text translation.
\end{abstract}

Index Terms - memetics, haihunhou state, archeology text

\section{INTRODUCTION}

Based on the biologist Darwin's evolutionism, memetics is a new theory to explain cultural evolution, which refers to the thoughts or ideas that are imitated and spread among the people in cultural field, and then are passed down from generation to generation. They survive by replicating and disseminating, so language is one of its carriers. In 1997, translation theorist Andrew Chesterman published Memes of Translation: The Spread of Ideas in Translation Theory, which laid the theoretical foundation for translation memetics. Since then, many scholars have actively participated in the study of the theory and applied it to the fields of teaching methodology, psychology, sociology and linguistics and so on. These researches have improved and enriched the theoretical framework of translation memetics to a certain extent.

In recent years, the archaeological excavation of Haihunhou State in Nanchang, provincial capital of Jiangxi, China, has gained wide attention at home and abroad. Royal Cemetery of Haihunhou State in Han Dynasty is the largest tomb which was a best-preserved settlement site in Han Dynasty with richest cultural relics for historical research in China. The book, The Archaeological Excavations at the Royal Cemetery of Haihunhou State in the Han Dynasty, vividly introduces the archaeological excavation works through the written records with a perfect balance between Chinese and English by colorful pictures. Nowadays, in the context of global cultural integration, it is worthy of our attention and effort to better spread Chinese archaeological achievements to the outside world. This paper will apply translation memetics as the theoretical tool to analyze and explore the translation phenomena in archeology text translation in the respects of meme replication and dissemination.

\section{THEORETICAL REVIEW}

Memetics originated from Darwin's famous evolution theory that "It's the biological law for natural selection and survival of the fittest". In 1890, French sociologist Gabriel Tarade proposed in his book The Laws of Imitation that social communication is the direct or indirect result of various forms of imitation, and he believed that the history of the entire society is also the history of imitation, which means that imitation could promote the generation of inspiration for invention, that is the common wealth of mankind. Then, in 1976, Oxford University scholar Richard Dawkins published his famous book The Selfish Gene, proposing the term "meme" for the first time and explaining how thoughts are spread from person to person by using "meme", and later, his student Blackmore published The Meme Machine, which continues to study "meme". Blackmore expanded the scope of memes and established memetic theory, thinking that any

\footnotetext{
* Supported by Study on the Publicity and English Translation of the Archaeological Excavations at the Royal Cemetery of Haihunhou Kingdom in the Han Dynasty in Nanchang, a Social Science Planned Research Project of Jiangxi Province in 2019 (19YY01).
} 
information which was obtained by imitation and copying can become a meme, also the characteristics and manifestations of the meme itself will make it easier to copy the meme. Subsequently, the researches on "meme" followed one after another and began to involve many more fields. Later in 1997, Finnish translation theorist Chesterman first combined "meme" with translation in his Memes of Translation: The Spread of Ideas in Translation Theory. He analyzes translation thoughts in various periods with the help of meme as the medium, then combined relevant translation concepts, viewpoints, strategies and values with memetics to systematically develop the theory "translation memetics".

The study of meme and translation memetics started late in domestic. On April 30, 2003, He Ziran and He Xuelin published an essay Memetics and Social Pragmatics in the magazine Modern Foreign Languages, which was the first to introduce this theory in domestic. And it is Professor He Ziran who first translated English word “meme” into “模因” in Chinese and then proposed and developed the translation memetics so as to study the law of language dissemination at the linguistic level from the perspective of memetics. He (2005) divides the transmitting methods of translation into two kinds-genotype and phenotype. Thereafter, Ma Xiao (2005) combines translation memetics with foreign language translation teaching, and suggests that teaching should follow the meme replication laws of assimilation, retention, expression and transmission. Yin Pi'an (2006) combines translation memetics and translation strategies to discuss the impact of meme dissemination on translation level. He believes that domesticated translation is a necessary stage for the early period of meme dissemination, while foreignized translation is the requirement and trend for meme dissemination. Zhuang Meiying (2008) extended the translation memetics to social pragmatics, and proposed to create advertising language memes with the help of meme transmission strategies, with the core idea is to regulate memes, strategic memes and value memes, and of course these three are related to each other (Huang Hui, 2014).

At present, domestic research on translation memetics focuses on these four aspects in turn: the introduction and further popularization of translation memetics, the enlightenment of memetics for translation teaching, the practical guidance from translation memetics, and the application of translation memetics in social pragmatic translation. It's not a long period for translation memetics development in domestic, while its future prospects are worth looking forward to.

\section{TRAnSLATION RESEARCH FROM THE PERSPECTIVE OF MEMETICS}

Meme replication is not a simple word-to-word correspondence between the original text and the source text from content to form. From the methods of meme replication and dissemination, memetics can be divided into two types: genotype and phenotype. In translation, genotype refers to "the same content but different forms", and phenotype refers to "the same form but different content" (He Ziran, 2005).

\section{A. Genotypic Translation}

The memetic translation in genotype is to replicate and disseminate the original ideas and information from the source text. For the same source information, the meme-expression may be the same or different in the process of replication and dissemination, but their content remains the same during this period (Luo Qian, 2018).

1. Synonymic Homomorphy

In some contexts, the information carrier can be transmitted directly without changing the form and content of the original text. When encountering a same or similar context with the original language, the meme will replicate and spread itself in this way.

\section{Source Text 1:}

海昏侯墓中发掘到海量五铢钱, 初步估算有 200 万枚, 海昏侯墓出土了 10 串左右的完整五铢钱, 每一串正好 是 1000 枚，将我国家“千文一贯”的币制单位由北宋上推到了西汉。

\section{Target Text 1:}

Massive numbers of Wuzhu coins were uncovered from Haihunhou cemetery. The number was primarily estimated to be 2 million, including 10 complete strings of 1000 coins. History of " $\mathbf{1 0 0 0}$ coins on one string" is pushed forward from the Northern Song Dynasty to the Western Han Dynasty. ${ }^{\text {[2] (P14) }}$

Analysis: The original text describes the excavation site when the royal cemetery of Haihunhou State was unearthed massive buried coins. Those coins called “五铢钱” in Chinese, the name of a kind of ancient coin which was named after the Chinese characters “五铢” covered on it. And another phrase the “千文一贯”means 1000 coins were tied in one string as a unit to measure the sum of coins. Those 1000 coins called “千文” in Chinese. So, the literal meaning of the two phrases “五铢钱” and “千文” is easy to understand in Chinese, and Chinese readers can quickly recognize the meaning of their expressions. Therefore, the translator adopts the method of Synonymic homomorphy to correspond"五 铢”as “Wuzhu”, “钱”as “coins”, “千文”as “1000 Coins” with the same morphological structure to express the same meaning. In this way, under the same context, the original meaning from source text can be imitated and disseminated in synonymic homomorphy, thus the target readers can fully receive the transmitted information without any major change in translation but in accordance with Chinese and English usage habits.

Source Text 2:

2015 年“中国考古六大新发现” 


\section{Target Text 2:}

Six Major Archaeological Discoveries in $2015^{[2](\mathrm{P} 7)}$

Analysis: The original text here is to describe the archaeological work in Haihunhou State which has won many awards in Chinese archaeology, one of which was "2015 Six New Discovery of Chinese Archaeology" selected by the Chinese Academy of Social Sciences. In the original text of “六大新发现”, “六”is a numeral, “大” is an adjective, “新” is also an adjective, these three Chinese characters were all used to modify the noun “发现”. This kind of structure is not only used in Chinese, but also in English and there is not any ambiguity here. Therefore, the translation of “六 大”adopts the synonymic homomorphy method, “六”corresponds to “six" in English, “大”corresponds to "major" in English. In this way, also under the same context, the information from original text can be replicated and transmitted in line with the language usage habits between Chinese and English. Without any major change, the readers can also fully receive the information conveyed by the translator for the language usage habits are conformed to both Chinese and English.

2. Heteromorphic Synonyms

This form of dissemination is also mainly based on replicating the content of original information, whose transmission is direct and progressive. During the translation of dissemination, the form of information may vary, but its original meaning of information will not be changed all the time. The content meaning after replicating still keeps consistent with that before.

Source Text 3:

考古发掘不仅仅是“挖土刨泥”, 他们不光要有“挖”的智慧, 更需要“掘”进历史的专业与经验。

\section{Target Text 3:}

Archaeological excavation is more than digging up soil and mud. Archaeologists, who should be wise in how to dig, should further bear expertise and experience of looking into history. ${ }^{[2](\mathrm{P} 147)}$

Analysis: This text is to describe the scene of excavation by archaeologists. In the original text, “挖土刨泥”actually has two parallel actions — “挖土” and “创泥”, but “挖土” and “创泥”in Chinese both refer to the action of excavating . Therefore, in English translation, the two actions of “挖” and “创” are combined into one predicate, and the objects of “土” and “泥” are placed after the predicate in turn. It is generally known that English is concise, so there just need one English verb to include of two actions “挖” and “创” in Chinese. The English translation of Chinese phrase“挖土刨泥” is not word-for-word, nevertheless they all express the same meaning with their own language characteristics. Then the original information is transmitted by changing the source text shape but expressing the same meaning and target readers can easily understand and accept.

\section{Source Text 4:}

\section{中央电视台科教频道《探索发现》栏目 6 月 30 日播出《海昏侯考古发掘现场》纪录片。}

\section{Target Text 4:}

Documentary of Archaeological Excavation Site of Haihunhou Great Tombs was on air at Discovery of CCTV (Science and Education) on March 30. ${ }^{[2](\mathrm{P} 39)}$

Analysis: The original meaning of “播出” in Chinese refers to the broadcasting of film or television works through the media, whose part of speech is a verb. Although "on air" in English often means "broadcasting on television or radio", it is a prepositional phrase. “播出” in Chinese does not correspond to "on air" in English word-for-word, while the meaning of the original text does not change under the different shape between Chinese and English. When translating, the translator translates the verbs in Chinese into prepositional phrases in English, which can enhance the impression and understanding of the original text for the target language readers. Though, under the different part of speech, their shapes may different in appearance, the readers can well know those words' meaning directly and may leave the imagination of the program broadcast.

\section{B. Phenotypic Translation}

The Phenotypic English translation meme refers to the meme which has the same form but different content with the source meme, and it is a horizontal, non-equivalent conversion of information from the source language to the target language meme (He Ziran, 2005). This type of meme may use the same form of expression, but expresses different content as needed.

1. Homonymy

Linguistic memes, while preserving the original structure, are grafted horizontally in a homonymous manner. These memes would successfully copy the form of the source text while increasing the interesting of the language, which can give readers a refreshing feeling for those new expressions and it also facilitate the further spread of source language information (Luo Qian, 2018).

Source Text 5:

开启内棺后，考古人员发现了更多的金饼与玉器。

Target Text 5:

Archaeologists have found more gold plates and jade wares after Main coffin is unveiled. 
[2] (P52)

Analysis: The translator translated the Chinese character“饼”into "plate", a round or oval flat dish used to hold some food or objects, but this is not its original meaning of “金饼”. Instead, Chinese phrase“金饼”is one of the forms of ancient Chinese gold currency, named after its round and flat shape. Therefore, in translation, the translator takes use of the similar shape between “金饼” and "plate”, then puts the meme of the“饼”in Chinese on the "plate” in English, so that the target language readers can associate the general appearance and meaning of “金饼” in Chinese when they draw its outline in mind because of translator's deliberational use of its associative meaning, which will also strengthen the spread of the meme of “金饼”in Chinese culture and make its background familiar to the outside.

\section{Source Text 6:}

\section{剥离清洗干净后的竹简, 字迹清晰可辨。}

\section{Target Text 6:}

This photo shows a cleaned-out bamboo slip, on which its writings are distinct to read.

Analysis: This text mainly introduces those unearthed cultural relics, especially stationery and writing materials. The original text of “竹简” is translated as "bamboo slip", where "slip" originally means a small piece of paper, especially one for writing on, which is obviously not adopting the original meaning of Chinese character"简”. Because "slip" is made by pulp ground from trees, while “竹简” is made of long and narrow bamboo pieces. However, the shape and function of "竹简" and "slip" are similar, and they are both long and narrow sheet-like objects used to record the characters and words, which is conducive to the dissemination of the "竹简" meme. So, in translation, the translator takes good use of this meme and disseminates “竹简” into "bamboo slip" so as to make target readers better understand the source language meaning and its culture background under the homonymy method by full use of human associative ability.

2. Homomorphic Association

Homomorphic association refers to the process that the language form has not changed in translation but generate different meaning association, which make target readers associate the contextual meaning of the original language with the literal form (Luo Qian, 2018).

Source Text 7:

盗墓分子精准地测定了主墓室正中位置, 并将楟板锯开, 距离主杽仅“一步之遥”。

\section{Target Text 7:}

Grave-robbers accurately located the center of the main tomb chamber and managed to carve out the chamber board. They were just "one step away" from the main coffin. ${ }^{[2](\mathrm{P} 45)}$

Analysis: The original word“遥”in the Chinese phrase “一步之遥”was originally a noun representing distance, but the translator used an adverb "away" here, which means distant in either space or time, as we used the phrase "one mile away" to show a mile distance from us. They both have the same structure of "number + quantifier + noun" in the phrase "one step away" from target text and "one mile away" from the example. Therefore, the translator applies a well-known phrase to create a potential phrase with the same form by the accumulation of existing knowledge which can also be accepted by the target language readers. At the same time, the adverb "away" may give people a sense of spatial association, as if "tomb-robbers only need to walk one step away from the main coffin". This way of association is also conducive to the spread of memes.

\section{Source Text 8:}

\section{随着文物一件件被提取，一个完整的西汉列侯大墓渐渐展现在世人面前。}

\section{Target Text 8:}

As heritages were hoisted from the tomb piece by piece, the complete cemetery of Haihunhou was exposed to the public. ${ }^{[2](\mathrm{P} 40)}$

Analysis: The original text describes the scene of the extraction of cultural relics and the word "hoist" originally means "hang up or pull up", which is used here to describe the "extraction" of cultural relics mentioned in original text. In addition to the literal meaning of "extract", there is also a sense of the images when the cultural relics are lifted up one by one. The translator employed homomorphic association when translating, allowing target language readers to associate with the images that cultural relics were lifted one after another carefully while sorting them out. In this way, it can be well expressed and accepted by the target readers whether from the surface information of those words to show the extraction scene or the associative meaning of the text to describe the rigorous archaeological work.

3. Homograph

In this kind of transmission, the structure and form of language memes are unchanged, but the content is changed and replaced with other words. Once the language model is finalized, the memes can be replicated and imitated so as to achieve the dissemination function of language (Luo Qian, 2018).

Source Text 9:

让海昏侯文化遗产“活”起来 


\section{Target Text 9:}

Let Cultural Heritage of Haihunhou Talk ${ }^{[2](P 27)}$

Analysis: In English, there are often a structure of "causative verb + verb stem" which means "allow someone to do something". The translator borrowed this structure in English and gave it the real meaning, and translated Chinese structure“让...活起来”into “Let...talk". Memetic is transmitted in the same structure and its target readers can get to know the source text meaning directly so that the primitive information will be successfully disseminated. Then, in the process of translation, the translator skillfully conveys the source language information with the help of the memes which had applied common structure in English. That would also facilitate the propagation of source memes by striking a responsive chord in the hearts of their readers.

\section{Source Text 10:}

\section{盗墓引发的考古发掘 不幸中之万幸}

\section{Target Text 10:}

Weal out of woe: archaeological excavation started from a grave-robbing incident ${ }^{[2](\mathrm{P} 47)}$

Analysis: The words in source text were used by the author to express his feeling for this archaeological work. In English, the structure “A out of B” means that A comes from B. In the source text, “不幸中之万幸”in Chinese refers to the fact that things are not so bad as to be hopeless, and there is still a possibility for luck. “不幸” and“万幸”are a set of opposites in Chinese. The translator applies this structure here to create the phrase "Weal out of woe" which means happiness comes from the suffering to express the meaning of “不幸中之万幸”in Chinese. What's more, “weal” and "woe" are a set of opposites in English, too. This is also a good reference to the symmetric structure of the phrase in source text. At the same time, these two words- "weal" and "woe" are in alliteration with beautiful rhyme, in line with English habits. So, in translation, the memes are hosted in the original English structure by changing the content without changing the form, then the target readers can quickly receive and remember the message in source text then they may consciously spread source language message.

\section{CONCLUSION}

"Meme" nowadays has become a culturally transmitting unit due to its own characteristics of continuous replication and dissemination, which has also accelerated the development and popularization of translation memetics. At the same time, translation memetics also provides a new theoretical perspective for translation research so that we can study translation by means of imitation, replication, and transmission instead of traditional linguistics perspectives. In the light of translation memetics, this paper interprets the positive role of language memes by discussing how the memes replicate and disseminate in Haihunhou Cemetery archeology text translation so as to provide an available reference in further archeology text translation.

\section{REFERENCES}

[1] Andrew Chesterman. (1997). Memes of Translation: The Spread of Ideas in Translation Theory. Amsterdam: John Benjamins.

[2] Chi Hong. (2016). The Archaeological Excavations at Royal Cemetery of Haihunhou State in Han Dynasty. Nanchang: Jiangxi pictorial Press.

[3] He Ziran \& He Xuelin. (2003). Memetics and Social Usage of Language. Modern Foreign Languages, 2, 201-209.

[4] He Ziran. (2005). Memes in Language. Linguistic Sciences, 6, 54-64.

[5] He Ziran. (2007). New Development in Pragmatics: Relevance, Adaptation and Memetics. Shanghai: Shanghai Educational Publishing House.

[6] Huang Hui. (2014). Chesterman's Translation Meme Theory. Data of Culture and Education, 9, 30-31.

[7] Luo Qian. (2018). Research and Practice of Applied Translation from the Perspective of Memetics. Shantou: Shantou University Press.

[8] Ma Xiao. (2005). Translation Memetics and Translation Teaching. Shandong Foreign Languages Teaching Journal, 3, $72-76$.

[9] Yin Pi'an. (2006). Memetics with Domestication and Alienation in Translation. Journal of Xi'an International Studies University, 1, 39-42.

[10] Zhuang Meiying. (2008). Meme Engineering-How to Build Contagious Advertising Language Memes. Foreign Language Research, 1, 83-87.

Cheng Dai was born in Jiangxi Province, China in 1996. She is currently a postgraduate in Translation Theory and Practice, Jiangxi Normal University, Nanchang, China.

Yuying Li was born in Jiangxi Province, China in 1964. She is currently a professor in Translation Theory and Practice, Jiangxi Normal University, Nanchang, China. She has published papers in both Chinese and international academic journals. 